\title{
EDITORIAL
}

\section{Sustainability Science Remains a Challenge for Academia}

\author{
Kamal Bawa *
}

Sustainability is the defining theme of this century. Sustainability Science based on the integration of a wide range of disciplines including arts and humanities is one of the means to achieve sustainability. The inclusion of arts and humanities indeed calls into the question the use of "science" in Sustainability Science. Putting this question aside, this journal itself is symbolic of efforts to nurture and foster Sustainability Science. The current issue covers a range of topics that constitute the core of Sustainability Science.

Forests in many countries of the global South are contested domains, with local communities and the state having different perspectives about the use and governance of forest ecosystems. In the opening essay, one of our leading thinkers on sustainability renews his call for new approaches to meet challenges related to governance of forest ecosystems. If integration of various types of knowledge is a key element of Conservation Science, integration of ideas, perspectives and approaches also underpins the practice of sustainability. And, indeed the merging of knowledge and practice is the basis of transdisciplinary Conservation Science.

The Conversations section with commentaries by prominent educators, who are bringing innovations in graduate programs, shows the ways to build the future leadership in Sustainability Science. Fresh thinking is also the key element of the Essay that explores the role of science and uncertainties in decision-making. Various research papers, notes from the

\footnotetext{
* Coordinating Editor (2018-19). University of Massachusetts, Boston, MA 02125-3393; and Ashoka Trust for Research in Ecology and the Environment (ATREE), Bengaluru, 560 064, India; kamal.bawa@gmail.com

Copyright (C) Bawa 2019. Released under Creative Commons Attribution-NonCommercial 4.0 International licence (CC BY-NC 4.0) by the author.

Published by Indian Society for Ecological Economics (INSEE), c/o Institute of Economic Growth, University Enclave, North Campus, Delhi 110007.
}

ISSN: 2581-6152 (print); 2581-6101 (web).

DOI: https://doi.org/10.37773/ees.v2i2.68 
field, reports and book review describe several other aspects of sustainability.

Altogether the articles in this issue show the promise and the distance the academia and society - as I also argued in in my editorial in the last issueneed to cover to make our world more sustainable. Although, the global community has set lofty goals in the form of United Nations Sustainable Development Goals to secure a better future for the planet and its people, the countries, especially in the global South, where sustainability challenges are becoming more severe day by day, have not taken steps to advance knowledge and practice that will ensure a sustainable future.

As the authors of various pieces in the Conversation section imply, nothing short of a radical transformation in curricula, the research enterprise, including funding, and the way knowledge is integrated with policies and action are required. We need far more centers in academia than what exists today. Sustainability Science centers are scarce even in the United States and Europe, and much fewer in countries of the South, posing a challenge that is not being addressed with the urgency it deserves.

South Asian countries and more specifically India with vast human resources and numerous institutions of learning have the means and successful indigenously developed models to encourage and support a major expansion of higher education programs in Sustainability Science. There is also considerable expertise in sustainability in the private sector, particularly in the information technology sector. There are thus opportunities for many types of partnerships to foster Sustainability Science

Within the universities, policy makers, university administrators and faculty have to accord the primacy to Sustainability Science. Everywhere, the undergraduate programs at most universities are woefully inadequate to prepare students for meeting the future societal challenges. It is inconceivable that in this day and age, any college or university can graduate a student without exposure to basic concepts and approaches underlying Sustainability Science.

The journal and the wide community that support the journal have an important role to play in articulating the case for the rapid expansion of research and education in Sustainability Science. Perhaps a future issue could explore the constraints to such an expansion and the ways to overcome such constraints at all educational levels. At stake is the planet's future, and by association, ours. 